\title{
Forest structural complexity in habitats with presence and absence of the Caucasian grouse (Lyrurus mlokosiewiczi) in the Arasbaran biosphere reserve, Iran
}

Sajad Ghanbari ( $\square$ ghanbarisajad@gmail.com )

University of Tabriz https://orcid.org/0000-0002-6568-1025

Kiomars Sefidi

University of Mohaghegh Ardabili

Pedro Álvarez-Álvarez

University of Oviedo: Universidad de Oviedo

\section{Research}

Keywords: Arasbaran biosphere reserve, coarse woody debris, species richness, structural complexity, Iran

Posted Date: February 26th, 2021

DOI: https://doi.org/10.21203/rs.3.rs-243688/v1

License: (c) (i) This work is licensed under a Creative Commons Attribution 4.0 International License.

Read Full License 


\section{Abstract}

Forest structural complexity can vary among different types of habitat and is defined by the dependency of species on resources. The positive relationship between structural complexity and forest functions is of increasing interest to researchers. In this study, we focused on the structural complexity of the habitat of the Caucasian grouse ( Lyrurus mlokosiewiczi ), which is an indicator species in mountain forest habitats in the Arasbaran biosphere reserve, Iran. Data were collected from previously identified presence and absence locations of this species. Three sample plots were chosen at random in each area (six sample plots in total). The main parameters measured were type of species, diameter and height of trees, shrub and regeneration, and number and diameter of coarse woody debris. Overstorey tree species richness differed in the absence and presence locations, with 16 and 12 species respectively. Understory species richness was also different in the absence ( 15 species) and presence (10 species) locations. The Caucasian grouse was observed in the site with trees smaller than $10 \mathrm{~cm}$ and a balanced density of trees smaller than $5 \mathrm{~cm}$. Overall, the $\mathrm{SCl}$ was higher in the absence location than in the presence location. The heterogeneity of the stand structure in grouse habitats was low. The area where the Caucasian grouse was present was characterized by small numbers of dead trees and also low log volume. Maintaining a heterogenous forest structure is important for protecting this species. Conservation of fruit trees that are fed on by the grouse is also recommended.

\section{Introduction}

Species diversity influences the quality of life in forests, and maintenance of such diversity is one of the most important tasks of forest management. A high degree of species diversity enhances ecological service provision by a large number species. The characteristics of stand structure can influence species diversity and habitat structure (Kara and Lhotka 2020). Forests are composed of a complex system with multiple attributes that interact with each other across different levels. Structural complexity is a measure of some attributes of forest stands and the relative value of each of these attributes. Given that the contribution of each structural attribute to forest complexity may vary consistently across stands (Sabatini et al. 2015), forest structural complexity can vary among different types of habitat (Caviedes and Ibarra 2017).

Determining the structural complexity of forest ecosystems is challenging, and several measures have been used to quantify aspects of structural complexity that focus on tree-based attributes, such as tree size differentiation, diversity of DBH classes, species richness, number of strata and other attributes related to tree and stand (Ehbrecht et al. 2017; McElhinny et al. 2006; Seidel et al. 2019b). Structural complexity necessarily involves the interactions between a number of different variables, and quantitative comparisons between stands may require complex multivariate analysis. In response to this problem, a variety of means have been devised to describe structural complexity by a single index, thereby facilitating comparisons between stands (McElhinny et al. 2005; Mensah et al. 2020; Sabatini et al. 2015). Structural complexity is assumed to positively affect several ecosystem functions and services provided by forests (De Groot 1992), including species diversity, resistance and resilience (Caviedes and 
Ibarra 2017). In terms of forest management, modern silviculture has focused on structural complexity (Kara and Lhotka 2020; Seidel et al. 2019a), defined as the way in which species depend on resources (Mensah et al. 2020). The heterogeneity of forest stand structure has a significant impact on tree-related microhabitats in forest ecosystems and enhances species richness (Sefidi and Copenheaver 2020).

The positive relationship between structural complexity and forest functions is of increasing interest to researchers. Some researchers have focused on the structural complexity and forest structure by applying different indices to different forest ecosystems throughout the world (Atsbha et al. 2019; Braunisch et al. 2019; McElhinny et al. 2005; Seidel et al. 2019a). The description of forest structure represents an important step in the process of understanding forest dynamics, forest ecosystem processes and the associated services (Gadow et al. 2012; Pretzsch 2009). Forest structure is the result of natural processes and human disturbances and it determines the distribution of micro-climatic conditions, the availability of resources and the formation of habitat niches and thus, directly or indirectly, the biological diversity within forest communities (Gadow et al. 2012). Intensive human interventions, including fire, logging, fuelwood harvesting and animal husbandry can potentially degrade the composition and availability of structural attributes in forests (Caviedes and Ibarra 2017). These types of interventions can alter the density of the understory, volume of coarse woody debris and the density of dead trees (Ghanbari et al. 2015). The loss of these forest attributes affects birds that depend on these key structural habitat attributes for their survival (Caviedes and Ibarra 2017; Ross et al. 2000; Sabatini et al. 2015). Coarse woody debris has been positively associated with avian diversity and abundance (Caviedes and Ibarra 2017). Standing coarse woody debris (i.e. dead trees) is an essential resource for many species of birds, especially birds that use the dead trees for breeding, perching, foraging, communicating and roosting (Lanham and Guynn Jr 1996; Lohr et al. 2002). In forests standing coarse woody debris is usually excavated and used for cavity-nesting by a variety of species (Tomasevic and Estades 2006). For example, Acosta-Jamett and Simonetti (2004) reported that coarse woody debris is an essential habitat for different species in loblolly pine forests in central Chile (Acosta-Jamett and Simonetti 2004). The value of coarse woody debris as bird habitat has also been documented by many other researchers (Mac Nally et al. 2001; Reid et al. 2004; Thiollay 1992; Tomasevic and Estades 2006).

In this research, we focused on the structural complexity of the habitat of the Caucasian grouse (Lyrurus mlokosiewiczi), considered an indicator species in mountain forest habitats. The Caucasian grouse, a forest bird species, was selected for determining different forest structural characteristics, as different response patterns can be expected in relation to the habitat requirements of the species, which will affect reserve designation. This indicator species is hypothesized to be affected by type of forest management in the long term. Thus, in the absence of disturbance, we expect forest closure and homogenization in the initial period after reserve designation to cause a decrease in habitat suitability for the species. To test our hypotheses, we compared structural complexity, as well as key habitat structures, in forest areas previously identified as presence and absence locations of the species. The study findings are expected to contribute to objectifying the debate around the effects of strict forest protection on mountain forest biodiversity, and to facilitate systematic reserve selection processes. 


\section{Materials And Methods}

\subsection{Study area}

This research was conducted in the Arasbaran deciduous forests in the northwest of Iran, in the Caucasus Iranian Highlands, at the border of Armenia and Azerbaijan. Since 1976, UNESCO has designated 72,460 ha of land in this area as a biosphere reserve, the Arasbaran biosphere reserve (Figure 1). The area covers mountains, high alpine meadows, semi-arid steppes, rangelands and forests, rivers and springs. The Arasbaran biosphere reserve provides habitat for more than 200 species of birds, notably the Caucasian grouse, grey partridge, black francolin and common pheasant, as well as 29 species of reptiles, 48 species of mammals, notably wild goat, wild boar, brown bear, wolf, lynx and leopard, and 17 species of fish (Darvishi et al. 2015). Arasbaran is also inhabited by several nomadic tribes, who mainly live in the buffer and transition zones. The minimum and maximum elevations in the study area are 450 and $2700 \mathrm{~m}$ above sea level (asl), respectively. The Caucasian black grouse (Lyrurus mlokosiewiczi) lives in uplands higher than $1800 \mathrm{~m}$ asl, mainly on the southern slopes, and it prefer forest edges and timberlines (Darvishi et al. 2015). The forest tree species typically include oak (Quercus macranthera), birch (Carpinus orientalis) and maple (Acer campestre), which occur in different proportions across the different elevations.

\subsection{Species description}

The species is known to occur in an area ranging from the Black Sea to the Caspian Sea in the Caucasus mountains in Russia, Georgia, Armenia and Azerbaijan in the north and east, over the little Caucasus in northeastern Turkey in the west to northwestern Iran in the south (Baskaya 2003). The Caucasian grouse is a sedentary species, breeding close to deciduous broadleaved forest in the Caucasus Mountains timberline. The forest habitas are typically dominated by Quercus macranthera. The population and distribution of this species have been declining over the last few decades (Baskaya 2003; BirdLifelnternational 2016; Habibzadeh et al. 2010). All areas where the species occurs in NW Iran are protected and designated as the Arasbaran biosphere reserve. The species has been reclassified as Near Threatened (NT) worldwide (Birdlife International 2016) and is listed as endangered in national Red Data books (Habibzadeh et al. 2013). The habitat of the species has been manipulated by human disturbance, forest management, strict protection and also by nomadic tribes in recent years. The Capercaillie, another species of grouse, strongly benefitted from forest-overexploitation in the second half of the 19th century and is now being negatively affected by the change from rotation forestry to selective cutting, which is associated with increasing canopy closure, lack of clearings and forest structural homogenization at the landscape scale (Suchant and Braunisch (2004) (Braunisch et al. 2019). A similar trend has been observed in the present study area. We hypothesize that the Caucasian grouse will be negatively affected in the near future by strict changes in forest protection resulting in canopy closure and the subsequent decrease in ground vegetation cover.

\subsection{Data collection and analysis}


In the first step, we selected forest locations where the Caucasian grouse was known to be present or absent. The distribution areas of the Caucasian grouse on the village maps made by the Forest, Rangelands, and Watershed Organization (FRWO) were identified within the Arasbaran biosphere reserve. The presence and absence locations of the species were identified using library studies and field surveys. Data on species presence and absence were supplied by ornithologists, foresters, hunters and local people, i.e. nomadic tribes (Braunisch et al. 2019). In each site, we randomly selected six sample plots from a total of 12 sample plots (Figure 1). The sample plots were of area 0.5 ha (dimensions $100 \mathrm{~m} \times 50$ $\mathrm{m}$ ) and in total, we surveyed plots covering a total area of 3 ha for each site.

\subsubsection{Forest structure}

In each sample plot, the species name and diameter at breast height (DBH) of all trees and shrubs were recorded. The DBH was measured with a tree caliper and the height of the trees, with a Suunto clinometer. Tree height is defined as the distance between the base and the top of a standing tree. Clinometers are used to measure individual tree height (Luoma et al. 2017). Trees larger than $1.3 \mathrm{~m}$ were classified into six size classes; $<5 \mathrm{~cm}, 5-10,10-15,15-20,20-25$ and $25-30 \mathrm{~cm}$. Tree height was classified at 1-m intervals for ten classes; $<2 \mathrm{~m}, 2-3 \mathrm{~m}, 3-4 \mathrm{~m}, 4-5 \mathrm{~m}, \ldots$, and $>10 \mathrm{~m}$. The number of understory seedlings ( $<1.3 \mathrm{~m}$ in height) was counted in each plot and used to calculate seedling density per hectare in each stand (Kara and Lhotka 2020). Plot basal area (BA) was calculated as the sum of the cross-sectional areas (at breast height) of all tree stems. The proportion of the respective species was calculated as the ratio between the species BA and the total BA of the stand (Juchheim et al. 2020).

The mean values and standard deviations of tree DBH and height were calculated for each sample plot. The relative frequency of three important species, Acer campestre, Carpinus orientalis and Quercus maranthera, was calculated in each plot.

Table 1: Description of attribute studied in the presence and absence locations 


\begin{tabular}{|c|c|c|}
\hline Attribute & Index & Description \& reference \\
\hline Stand strata & $\begin{array}{l}\text { Number of } \\
\text { strata }\end{array}$ & $\begin{array}{l}\text { The number of strata was determined, considering that multi-layered } \\
\text { stands increase the diversity of habitat niches (McElhinny et al. 2005). }\end{array}$ \\
\hline \multirow{4}{*}{$\begin{array}{l}\text { Tree } \\
\text { diameter }\end{array}$} & Tree DBH & Tree DBH generally increases with stand age. \\
\hline & $\begin{array}{l}\text { The } \\
\text { standard } \\
\text { deviation of } \\
\text { DBH }\end{array}$ & $\begin{array}{l}\text { The standard deviation of tree } \mathrm{DBH} \text { is a measure of the variability in tree } \\
\text { size and is considered indicative of the diversity of micro-habitats within a } \\
\text { stand. }\end{array}$ \\
\hline & $\begin{array}{l}\text { Tree size } \\
\text { diversity } \\
\text { (TSD) }\end{array}$ & $\begin{array}{l}\text { Shannon-Weiner Index was used to summarize } \mathrm{DBH} \text { distribution in a single } \\
\text { measure called TSD }(\mathrm{H} \square) \text {, where } \mathrm{H} \square=- \text { and pi is the proportion of trees in } \\
\text { the ith DBH class. The 10-15 } \mathrm{DBH} \text { class was considered a reference } \mathrm{DBH} \\
\text { class (Wikström and Eriksson 2000). }\end{array}$ \\
\hline & $\begin{array}{l}\text { Diameter } \\
\text { distribution }\end{array}$ & $\begin{array}{l}\text { The DBH distribution indicates something about the stand structure. Stands } \\
\text { with a reverse J distribution are indicative of uneven-aged stands (Peng } \\
\text { 2000). Also, it is as an attribute of forest structure is the complexity of } \\
\text { comparing distributions from different stands (McElhinny et al. 2005). }\end{array}$ \\
\hline \multirow[t]{3}{*}{ Tree height } & $\begin{array}{l}\text { Height of } \\
\text { overstorey }\end{array}$ & $\begin{array}{l}\text { The simplest attribute associated with height is the height of the } \\
\text { overstorey. This attribute may be indicative of successional stage, the } \\
\text { number of strata or stand biomass. The overstorey tree layer included all } \\
\text { trees with a DBH } \geq 10 \mathrm{~cm} \text { (Zhang et al. 2017). }\end{array}$ \\
\hline & $\begin{array}{l}\text { Standard } \\
\text { deviation of } \\
\text { tree height }\end{array}$ & $\begin{array}{l}\text { The standard deviation of tree height will be more indicative of the vertical } \\
\text { layering of foliage than the standard deviation of } \mathrm{DBH} \text {. }\end{array}$ \\
\hline & $\begin{array}{l}\text { Horizontal } \\
\text { variation in } \\
\text { height } \\
(\% \mathrm{CV})\end{array}$ & $\begin{array}{l}\text { Variation in tree height is considered an important attribute of structure } \\
\text { because stands including a variety of tree heights are also likely to contain } \\
\text { a variety of tree ages and species (McElhinny et al. 2005). }\end{array}$ \\
\hline
\end{tabular}

Stand basal

area

Tree

species
Stand basal area is directly related to mean DBH. It is also indicative of stand volume and biomass.

Species The number of species per sample plot (Atsbha et al. 2019; Maua et al. richness 2020)

Relative The ratio between the frequency of a species and the sum of all species frequency frequencies (Haq et al. 2019; Maua et al. 2020)

of key

species

Understorey Shrub vegetation height Understory richness

Deadwood Number, basal area and volume
The understorey tree layer included all trees with a $\mathrm{DBH}<10 \mathrm{~cm}$ and $\geq 1.3$ $\mathrm{m}$ in height (Zhang et al. 2017).

Species richness was estimated in each sample plot and per ha. Understorey species richness due to the increased interspecific competition may lead to reducing resource availability (Zhang et al. 2017).

Dead standing and fallen trees are considered key structural elements. In natural forests, a wide variety of dead wood forms correspond to the continuity of wood decomposition, ranging from dead branches still attached 
of dead to tree crowns, standing dead trees to rotting logs (Fröhlich and Ciach trees 2020). Number, BA, and volume of dead trees were classified in 4 classes.

(by decay

classes)

\subsubsection{Structural complexity index}

All indices were calculated accurately and used to determine the Structural complexity index (SCl). For indexes showing high kurtosis $(<2)$, logarithm and square-root transformations were used to improve the distribution of the values. Regression analysis through quartiles was then performed to rescale each of the twelve selected stand-structural indices to a score ranging from 0 to 10 (Table 3). Scores of 2.5, 5, 7.5 and 10 were set to the quartile midpoints corresponding to the $12.5,37.5,62.5$ and 87.5 percentiles of the raw data distribution (McElhinny et al. 2006; Sabatini et al. 2015). A maximum score of 10 was attributed to the 87.5 percentile, while the equation was constrained so that the minimum score was 0 . The structural complexity index was obtained by adding all 12 rescaled values, with 0 being the minimum and 120 being the maximum additive value. Thus, the total value of a stand with high structural complexity would be closer to 120 , while the total value of a less structurally complex stand would be closer to 0 (McElhinny et al. 2006; Sabatini et al. 2015).

The Gini coefficient was used to analyze the degree of regularity of size structures. This index enables comparison of the DBH structures of different stands. It is obtained from the area between the $45^{\circ}$ line and the Lorenz curve, which in turn was derived by plotting the cumulative basal area proportions of trees per hectare against the cumulative proportions of the number of trees per hectare, after ranking the DBH data in ascending order. As the values range from 0 to 1 , the Gini coefficient is easy to interpret. It has a minimum value when all of the trees are of equal size (Bourdier et al. 2016; Pach and Podlaski 2015).

\section{Results}

Overstorey tree species richness was different in the absence (16) and presence (12) locations. The following tree species were observed in the absence location: Acer campestre, Berberis sp., Carpinus orientalis, Cornus sanguinea, Cratagus meyeri, Euonymus sp., Fraxinus excelsiour, Juniperus excelsa, Malus domestica, Mespilus sp., Prunus domestica, Pyrus sp., Quercus macranthera, Smilax $s p$. and Viburnum lantana (=15). The following species were observed in the presence location: Acer campestre, Carpinus orientalis, Cornus sanguinea, Fraxinus excelsiour, Malus domestica, Prunus domestica, Pyrus sp., Quercus macranthera, Ribes biberestentii, Rosa canina, Sorbus aucuparia and Viburnum lantana. The most abundant species in the presence area was Ribes biberestentii.

The frequency of overstorey trees in the different DBH classes differed between the areas with absence and presence of the Caucasian grouse (Figure 2). The number of trees was higher in the absence location than in the presence location. In the absence location, most of the trees corresponded to DBH class 5-10 (1242 stems/ha), while the frequency of trees in the $<5$ class was relatively high ( 533 stems/ha) in the 
presence location. In almost all DBH classes, the frequency of trees in the absence location was higher than in the presence location, except for DBH class $<5 \mathrm{~cm}$. Differences between absence and presence location were observed for all size classes. Large differences were observed in DBH class $5-10 \mathrm{~cm}$ (1242:388 stems/ha).

Understory species richness differed in the absence (15) and presence (10) locations. The following species were observed in the absence location: Acer campestre, Berberis sp., Carpinus orientalis, Cornus sanguinea, Cotoneaster sp., Crataegus meyeri, Euonymus sp., Juniperus excelsa, Malus domestica, Mespilus sp., Prunus domestica, Quercus macranthera, Rosa canina, Smilax sp. and Viburnum lantana. The following species were observed in the presence location: Acer campestre, Cornus sanguinea, Cotoneaster sp., Malus domestica, Prunus domestica, Quercus macranthera, Ribes biebersteinii, Rosa canina, Sorbus aucuparia and Viburnum lantana.

The number of understory trees including saplings and seedlings per hectare is shown in Figure 3 . The number of understory trees in all height classes was greater in the presence location than in the absence location (Figure 3). A difference between absence and presence locations was also observed in DBH classes. The frequency of understory trees of all three DBH classes was higher in the presence location than in the absence location. This difference was relatively large for height class $100-130 \mathrm{~cm}(25: 153)$ and DBH class 2.5-5 cm (15:103).

The mean value of 12 selected structural attributes in the absence and presence locations of the Caucasian grouse are shown Table 2. The mean DBH was lower in the absence location than in the presence location. The values of some other attributes such as horizontal variation in DBH, maximum $\mathrm{DBH}$, frequency of stems smaller than $5 \mathrm{~cm}$ and understorey stems per ha were lower than in the presence location. By contrast, the values of other characteristics such as TSD, height of overstorey, height class richness, species richness, density of dead trees and log volume were higher in the presence location than in the absence location.

Table 2: Mean values and SD $(n=12)$ for a selection of structural attributes in the absence and presence locations of the Caucasian grouse 


\begin{tabular}{llll}
\hline & Indices & Absence (mean \pm sd) & Presence (mean \pm sd) \\
\hline 1 & Mean DBH & $9.63 \pm 4.36$ & $10.37 \pm 5.66$ \\
2 & Tree size diversity (TSD) & 0.367 & 0.358 \\
\hline 3 & Horizontal variation in DBH (\%CV) & 45.2 & 54.6 \\
\hline 4 & Maximum DBH & 30 & 45.5 \\
\hline 5 & Gini coefficient & 0.53 & 0.37 \\
\hline 6 & Frequency of stems smaller than $5 \mathrm{~cm}$ & 677 & 1598 \\
\hline 7 & Height of overstorey & $5.66 \pm 3.54$ & $3.56 \pm 1.17$ \\
\hline 8 & Height class richness & 9 & 6 \\
\hline 9 & Species richness & 16 & 12 \\
\hline 10 & Understory stem/ha & 212 & 641 \\
\hline 11 & Number of dead trees (n) & 1254 & 152 \\
\hline 12 & Log volume & 10.26 & 0.65 \\
\hline
\end{tabular}

To provide an objective starting point for combining core attributes in an index framework, the core attributes were rescaled as scores from 0 to 10 by using equations that modelled attribute scores as a function of the raw attribute data. The set of equations for scoring the 12 attributes is shown in Table 3. The equations were constrained so that the rescaled score was always between 0 and 10 . This approach led to very little loss of information in the rescaling process.

Table 3: Regression equations used to assign a score to the quantitative values of indices on a scale of 0-10

\begin{tabular}{llll}
\hline & Index & Regression equation & $\mathrm{R}^{2}$ \\
\hline 1 & Mean of DBH & Score $=-8.1+\mathrm{X} \cdot 1.49$ & 0.903 \\
2 & Tree size diversity (TSD) & Score $=-55.247+\mathrm{X} \cdot 176.22$ & 0.934 \\
\hline 3 & Horizontal variation in DBH $(\mathrm{CV})$ & Score $=-13.292+\mathrm{X} \cdot 2.95$ & 0.995 \\
\hline 4 & Maximum DBH & Score $=-11.751+\mathrm{X} \cdot 0.78$ & 0.981 \\
\hline 5 & Gini coefficient & Score $=-3.981+\mathrm{X} \cdot 22.67$ & 0.936 \\
\hline 6 & Frequency of smaller than $5 \mathrm{~cm}$ & Score $=2.542+\mathrm{X} \cdot 0.22$ & 0.988 \\
\hline 7 & Height of overstory & Score $=-6.853+\mathrm{X} \cdot 3.121$ & 0.928 \\
\hline 8 & Height class richness & Score $=-4.872+\mathrm{X} \cdot 1.68$ & 0.978 \\
\hline 9 & Species richness & Score $=-3.489+\mathrm{X} \cdot 1.04$ & 0.897 \\
\hline 10 & Understory stem/ha & Score $=3.862+\mathrm{X} \cdot 0.17$ & 0.851 \\
\hline 11 & Number of dead trees $(\mathrm{n})$ & Score $=3.879+\mathrm{X} \cdot 0.14$ & 0.843 \\
\hline 12 & Log volume & Score $=3.824+\mathrm{X} \cdot 6.97$ & 0.843 \\
\hline
\end{tabular}

Correlation coefficients for different stand attributes in the absence and presence locations are shown in Table 4. The structural complexity index was positively correlated with trees of DBH smaller than $5 \mathrm{~cm}$, height of overstorey, number of dead trees and log volume. 
Table 4: Correlation coefficients for different stand attributes in the absence and presence locations

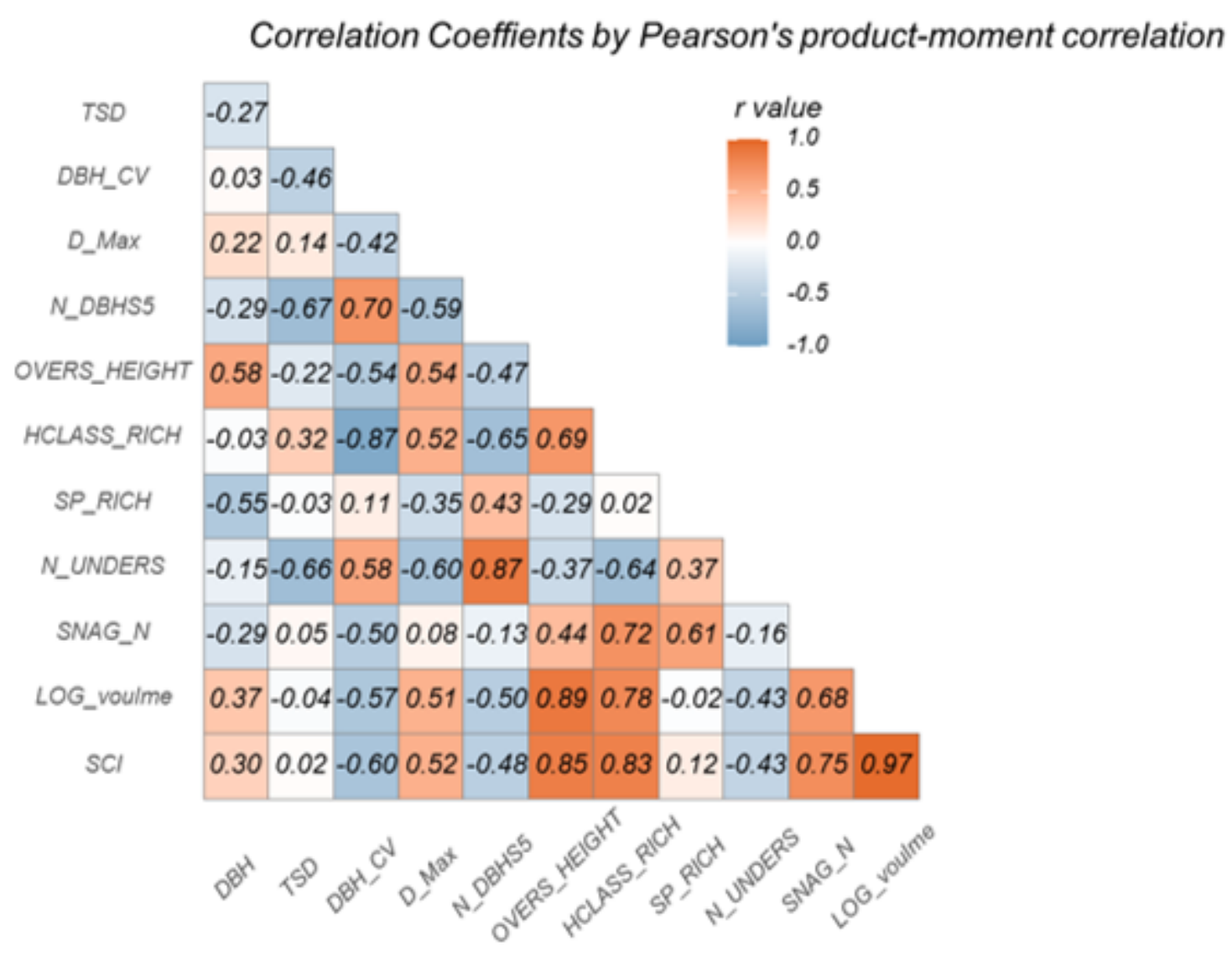

Figure 4 shows the density of all trees and trees smaller than $5 \mathrm{~cm}$ in diameter in two absence and presence locations. Comparison of the density of trees in the DBH distribution classes showed that in the presence location, most of the trees were of DBH less than $10 \mathrm{~cm}$ but no great difference in the absence location. Unlike the density of all trees in both regions, a high density of trees with DBH smaller than $5 \mathrm{~cm}$ was observed in the absence location while the density was balanced in the presence area. The Caucasian grouse was observed in the site with trees smaller than $10 \mathrm{~cm}$ and a balanced density of trees smaller than $5 \mathrm{~cm}$. In the presence location, the forets understory is currently being reestablished.

The TSD provides an estimate of the ratio of trees in the DBH class 10-15 as a reference DBH class for all trees in the sample plots. The TSD values were higher in the absence location than in the presence location, although the difference was not significant (Figure 5). The frequency of trees in the 10-15 DBH classes was higher in the absence location than in the presence location. The CV of DBH indicated a significant difference between the two locations. According to the $\mathrm{CV}$ of $\mathrm{DBH}$, the variation in $\mathrm{DBH}$ in the presence location was higher than in the absence location and the structure was more heterogeneous. The species was observed in a region with different DBH. However, in the absence location, the DBH of trees was similar, with a low CV of DBH. In all sample plots in the absence location, the structural 
complexity index $(\mathrm{SCl})$ for the Caucasian grouse was higher than in the presence location. In total, the $\mathrm{SCl}$ was higher in the absence location than in the presence location. Grouse habitats had low SCl values (Figure 5). The SCl differed significantly (at the 0.001 level) between absence and presence locations. The number of understory trees differed significantly between the two regions without the size of understory trees (Figure 5).

In the presence area, the forest floor was barer, without accumulation of dead trees. The presence location of the Caucasian grouse was characterized by small numbers of dead trees and also a low log volume. The number of dead trees differed significantly (at the 0.01 level) between the two areas (Figure $6)$.

\section{Discussion}

Forests provide habitats for diverse wildlife and grouse species. The dependency of species on resources varies with the habitat location as a combined variable in forest structural complexity. This research focused on forest structural complexity in the locations where the Caucasian grouse was absent and present. Determination of forest structural complexity $(\mathrm{SCl})$ and the type of forest management in the absence locations by patterning from the presence area is a key for preservation of most of this species habitat throughout the Arasbaran biosphere reserve.

Overstorey tree species richness was lower in the presence location (12 species) than in the absence location (16 species). These observations are consistent with the findings of Braunisch et al (2019), who reported that some grouse species such as Capercaillie benefit from overexploitation and thrive in the early forest successional stages.

The Caucasian grouse depends on forests for foraging and feeding. The type of plant species present is the main factor determining habitat selection. The presence of bilberry (Vaccinium myrtillus) was mentioned as the main factor in the selection of forest habitat by another type of grouse, i.e. the Capercaillie (Tetrao urogallus), in central Europe (Braunisch et al. 2019; Storch 1993). Another species in the berry family, the red currant (Ribes biberestentii) was found in the Caucasian grouse presence location. These fruits provide high energy for this species. Low or lack of access to food sources such as red currant (Ribes biberestentii) can reduce the habitat suitability for adult grouse. Indeed, preferred food availability may explain the absence of birds in structurally heterogeneous forests as grouse species are often absent from highly developed, complex forest structures. Natural and artificial threats can lead to strong dependence of the species on the presence locations. In other areas, with the complex structure of oak and a high degree of competitiveness, fruit trees on which the Caucasian grouse feeds are eliminated, thus limiting the presence of this species.

Although Schäublin and Bollmann (2011) reported that forest practices have not inhibited the development of light-demanding food species of the genera Sorbus, Rosa, etc., we observed some of these species (e.g. Ribes biebersteinii, Rosa canina, Sorbus aucuparia and Viburnum lantana) in the 
presence location. In addition to fruit, the buds and catkins of these trees represent important elements of the winter food for these bird species (Müller et al. 2009).

The structural complexity index (SCl) values were higher in the Caucasian grouse absence location than in the presence location. Grouse habitats had a low SCl value (Figure 5). This finding contrasts with those of Braunisch et al (2019), who reported that the Capercaillie is negatively affected by the results of selective cutting, such as increasing canopy closure, lack of clearings and homogenization of forest structurel. SOther researchers reported that the lower structural complexity index due to widespread conversion of structurally heterogeneous stands to uniform, single-layered stands may have caused the hazel grouse populations to decline (Schäublin and Bollmann 2011).

The number of understory trees differed significantly between the two types of location (Figure 5). The presence location had a dense understorey, which the Caucasian grouse prefers. Similar findings have been reported for the Capercaillie (Storch, 1993). A well-developed understorey with deciduous species is essential for ensuring optimal availability of food for the Caucasian grouse. Understory vegetation can also provide for cover for grouse chicks during the snow-free season and help to protect them from natural and artificial threats such as predators and game hunters (Müller et al. 2009; Schäublin and Bollmann 2011). This is consistent with our findings of high-density understorey in early-stage succession forests.

The importance of coarse woody debris in the diversity and abundance of bird species has been emphasized by many researchers (Acosta-Jamett and Simonetti 2004; Mac Nally et al. 2001; Tomasevic and Estades 2006). Birds depend on coarse woody debris for different uses. Although a positive relationship between coarse woody debris and avian diversity and abundance has been reported (Lohr et al. 2002), our findings showed that the presence of the Caucasian grouse was associated with a small number of dead trees and low volume of logs. The Caucasian grouse nests on the ground and below shrubs, and the presence coarse woody debris in the understory and on the ground may hinder nesting. Collection of coarse woody debris as fuelwood in the Caucasian grouse presence area has decreased the number of dead trees and log volume (Ghanbari et al. 2015). In other studies, exploitation of coarse woody debris as fuelwood has been recommended (Mac Nally et al. 2001). However, in the present study coarse woody debris was strongly correlated with forest structural complexity (with number of dead trees $=0.75$ and log volume $=0.97$ ).

The present study analyzed data on the stand structure that provides vital information about the presence of the Caucasian grouse and habitat suitability, with the aim of developing effective conservation programmes and plans. In this respect, particular effort should be made to preserve highly suitable habitat and surroundings areas from anthropogenic disturbance to prevent future threats to the population, as has occurred in other cases in Europe (Quevedo et al. 2006).

\section{Conclusion}


This study focused on the difference between the areas where the Caucasian grouse is present and absent in the Arasbaran biosphere reserve in Iran. The study findings showed that the structural complexity index values were lower in the presence location than in the absence location. Some lightdemanding plant species such as Ribes biebersteinii, Rosa canina, Sorbus aucuparia and Viburnum lantana identified in the presence area provide food for the bird species in the form of fruit during the summer and buds and catkins during the winter. Therefore, we suggest that silviculature management should increase the density of fruit-bearing species as food sources for the Caucasian grouse. We also confirmed that dense understory vegetation helps to protect the Caucasian grouse from different threats, as found by other researchers (Schäublin and Bollmann 2011). Many researchers who emphasize that the presence of coarse woody debris increases the presence of bird species (Acosta-Jamett and Simonetti 2004; Tomasevic and Estades 2006). However, we only found small amounts of coarse woody debris in the areas where this bird species was present, as local residents collect the woody debris as firewood (Ghanbari et al. 2015). We thus recommend decreasing forest structural complexity by encouraging the removal of coarse woody debris in the Caucasian grouse habitat. However, the effects of human disturbance on forest structure and the Caucasian grouse population requires further study. Maintaining a heterogeneous forest structure is important to help protect this species. We also recommend that fruit trees on which this species feeds should be preserved in the forest structure. Future studies should address the long-term effects of natural and artificial disturbances on forest structure and biodiversity.

\section{Declarations}

\section{Ethics approval and consent to participate}

"Not applicable"

\section{Consent for publication}

“Not applicable"

\section{Availability of data and materials}

The datasets used and/or analysed during the current study are available from the corresponding author on reasonable request.

\section{Competing Interest}

"The authors declare that they have no competing interests"

\section{Funding:}

This research did not receive any specific grant from funding agencies in the public, commercial or notfor-profit sectors. 


\section{Author Contributions}

Conceptualization, Formal analysis, Methodology, S.G. and K.S; Writing-original draft, S.G., K.S; Supervision, P.A.A; Writing-review and editing, K.S and P.A.A. All authors have read and agreed to the published version of the manuscript.

\section{Acknowledgements}

The authors acknowledge the Iranian Department of Environment, the Bureau of Environment of East Azerbaijan, and the Environment Office of Kalibar County for their support during this research. Special thanks are also given to the local residents of the study area for sharing their knowledge. We are very grateful to the reviewers who provided valuable comments on an earlier version of the manuscript.

\section{References}

Acosta-Jamett G, Simonetti JA (2004) Habitat use by Oncifelis guigna and Pseudalopex culpaeus in a fragmented forest landscape in central Chile Biodiversity \& Conservation 13:1135-1151

Atsbha T, Desta AB, Zewdu T (2019) Woody species diversity, population structure, and regeneration status in the Gra-Kahsu natural vegetation, southern Tigray of Ethiopia Heliyon 5:e01120

Baskaya S (2003) Distribution and principal threats to Caucasian black grouse Tetrao mlokosiewiczi in the Eastern Karadeniz Mountains in Turkey Wildlife Biology 9:377-383

BirdLifelnternational (2016) Lyrurus mlokosiewiczi. The IUCN Red List of Threatened Species 2016:

e.T22679483A92815595. doi:http://dx.doi.org/10.2305/IUCN.UK.2016-3.RLTS.T22679483A92815595.en

Bourdier T, Cordonnier T, Kunstler G, Piedallu C, Lagarrigues G, Courbaud B (2016) Tree size inequality reduces forest productivity: an analysis combining inventory data for ten European species and a light competition model PloS one 11:e0151852

Braunisch V, Roder S, Coppes J, Froidevaux JS, Arlettaz R, Bollmann K (2019) Structural complexity in managed and strictly protected mountain forests: effects on the habitat suitability for indicator bird species For Ecol Manage 448:139-149

Caviedes J, Ibarra JT (2017) Influence of anthropogenic disturbances on stand structural complexity in Andean temperate forests: implications for managing key habitat for biodiversity PloS one 12:e0169450

Darvishi A, Fakheran S, Soffianian A (2015) Monitoring landscape changes in Caucasian black grouse (Tetrao mlokosiewiczi) habitat in Iran during the last two decades Environmental monitoring and assessment 187:443

De Groot RS (1992) Functions of nature: evaluation of nature in environmental planning, management and decision making. Wolters-Noordhoff BV, 
Ehbrecht M, Schall P, Ammer C, Seidel D (2017) Quantifying stand structural complexity and its relationship with forest management, tree species diversity and microclimate Agricultural and Forest Meteorology 242:1-9

Fröhlich A, Ciach M (2020) Dead tree branches in urban forests and private gardens are key habitat components for woodpeckers in a city matrix Landscape and Urban Planning 202:103869

Gadow Kv et al. (2012) Forest structure and diversity. In: Continuous cover forestry. Springer, pp 29-83

Ghanbari S, Jafari M, Nasiri V (2015) Effects of conservation programs in changing the pattern of fuel consumption of villagers in the Arasbaran forests Journal of Forest Research and Development 1:67-83

Habibzadeh N, Karami M, Alavipanah SK, Riazi B (2013) Landscape Requirements of Caucasian Grouse (Lyrurus mlokosiewiczi) in Arasbaran Region, East Azerbaijan, Iran The Wilson Journal of Ornithology 125:140-149

Habibzadeh N, Karami M, Tarinejad A (2010) Caucasian black grouse (Tetrao mlokosiewiczi) breeding display sites selection in Arasbaran region, East Azerbaijan, Iran Russian journal of ecology 41:450-457

Haq SM, Rashid I, Khuroo AA, Malik ZA, Malik AH (2019) Anthropogenic disturbances alter community structure in the forests of Kashmir Himalaya Tropical Ecology 60:6-15

Juchheim J, Ehbrecht M, Schall P, Ammer C, Seidel D (2020) Effect of tree species mixing on stand structural complexity Forestry: An International Journal of Forest Research 93:75-83

Kara F, Lhotka JM (2020) Comparison of unmanaged and managed Trojan Fir-Scots pine forests for structural complexity Turkish Journal of Agriculture and Forestry 44:62-70

Lanham JD, Guynn Jr DC (1996) Influences of coarse woody debris on birds in southern forests Biodiversity and coarse woody debris in southern forests US Forest Service Technical Report SE-94 Washington, DC: United States Forest Service:101-107

Lohr SM, Gauthreaux SA, Kilgo JC (2002) Importance of coarse woody debris to avian communities in loblolly pine forests Conservation Biology 16:767-777

Luoma V, Saarinen N, Wulder MA, White JC, Vastaranta M, Holopainen M, Hyyppä J (2017) Assessing precision in conventional field measurements of individual tree attributes Forests 8:38

Mac Nally R, Parkinson A, Horrocks G, Conole L, Tzaros C (2001) Relationships between terrestrial vertebrate diversity, abundance and availability of coarse woody debris on south-eastern Australian floodplains Biological Conservation 99:191-205

Maua JO, MugatsiaTsingalia H, Cheboiwo J, Odee D (2020) Population structure and regeneration status of woody species in a remnant tropical forest: A case study of South Nandi forest, Kenya Global Ecology 
McElhinny C, Gibbons P, Brack C (2006) An objective and quantitative methodology for constructing an index of stand structural complexity For Ecol Manage 235:54-71

McElhinny C, Gibbons P, Brack C, Bauhus J (2005) Forest and woodland stand structural complexity: its definition and measurement For Ecol Manage 218:1-24

Mensah S, Salako VK, Seifert T (2020) Structural complexity and large-sized trees explain shifting species richness and carbon relationship across vegetation types Functional Ecology 34:1731-1745

Müller D, Schröder B, Müller J (2009) Modelling habitat selection of the cryptic Hazel Grouse Bonasa bonasia in a montane forest Journal of Ornithology 150:717-732

Pach M, Podlaski R (2015) Tree diameter structural diversity in Central European forests with Abies alba and Fagus sylvatica: managed versus unmanaged forest stands Ecological Research 30:367-384

Peng C (2000) Growth and yield models for uneven-aged stands: past, present and future For Ecol Manage 132:259-279

Pretzsch H (2009) Forest dynamics, growth, and yield. In: Forest dynamics, growth and yield. Springer, pp 1-39

Quevedo M, Bañuelos MJ, Obeso JR (2006) The decline of Cantabrian capercaillie: How much does habitat configuration matter? Biological Conservation 127:190-200

Reid S, Díaz IA, Armesto JJ, Willson MF (2004) Importance of native bamboo for understory birds in Chilean temperate forests The Auk 121:515-525

Ross B et al. (2000) Relative abundance and species richness of herpetofauna in forest stands in Pennsylvania Forest Science 46:139-146

Sabatini FM, Burrascano S, Lombardi F, Chirici G, Blasi C (2015) An index of structural complexity for Apennine beech forests iForest-Biogeosciences and Forestry 8:314

Schäublin S, Bollmann K (2011) Winter habitat selection and conservation of Hazel Grouse (Bonasa bonasia) in mountain forests Journal of Ornithology 152:179-192

Sefidi K, Copenheaver CA (2020) Tree-Related Microhabitats: A Comparison of Managed and Unmanaged Oriental Beech-Dominated Forests in Northern Iran Forest Science

Seidel D, Ehbrecht M, Annighöfer P, Ammer C (2019a) From tree to stand-level structural complexityWhich properties make a forest stand complex? Agricultural and Forest Meteorology 278:107699 
Seidel D, Ehbrecht M, Dorji Y, Jambay J, Ammer C, Annighöfer P (2019b) Identifying architectural characteristics that determine tree structural complexity Trees 33:911-919

Storch I (1993) Habitat selection by capercaillie in summer and autumn: is bilberry important? Oecologia 95:257-265

Thiollay J-M (1992) Influence of selective logging on bird species diversity in a Guianan rain forest Conservation biology 6:47-63

Tomasevic JA, Estades CF (2006) Stand attributes and the abundance of secondary cavity-nesting birds in southern beech (Nothofagus) forests in south-central Chile Ornitologia Neotropical 17:1-14

Wikström P, Eriksson LO (2000) Solving the stand management problem under biodiversity-related considerations For Ecol Manage 126:361-376

Zhang Y, Chen HY, Taylor AR (2017) Positive species diversity and above-ground biomass relationships are ubiquitous across forest strata despite interference from overstorey trees Functional Ecology 31:419426

\section{Figures}

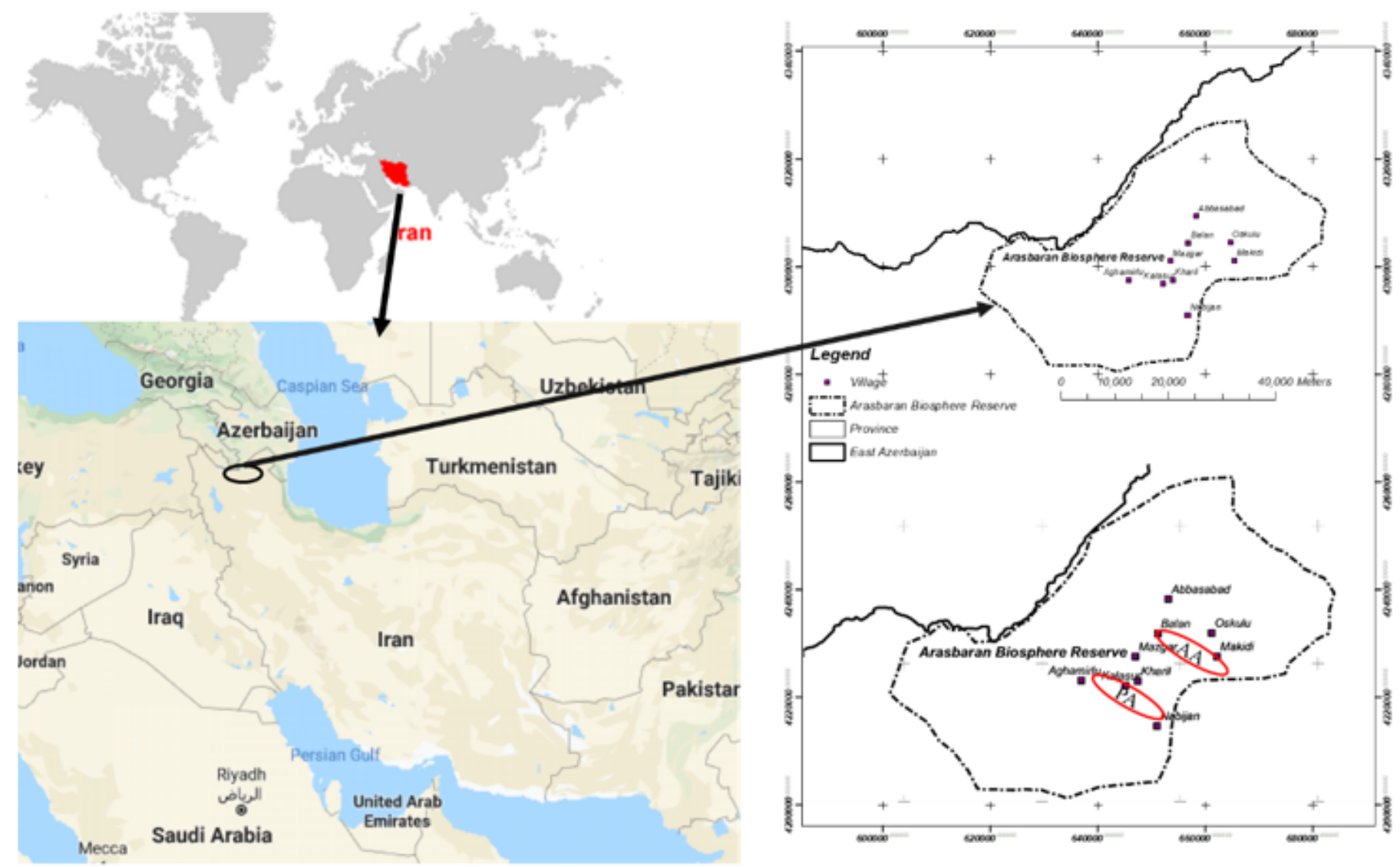


Figure 1

Map of the study area showing the presence and absence locations of the Caucasian grouse (Lyrurus mlokosiewiczi) in the Arasbaran Biosphere Reserve, NW Iran. PL: Presence location, AL: Absence location. Note: The designations employed and the presentation of the material on this map do not imply the expression of any opinion whatsoever on the part of Research Square concerning the legal status of any country, territory, city or area or of its authorities, or concerning the delimitation of its frontiers or boundaries. This map has been provided by the authors.

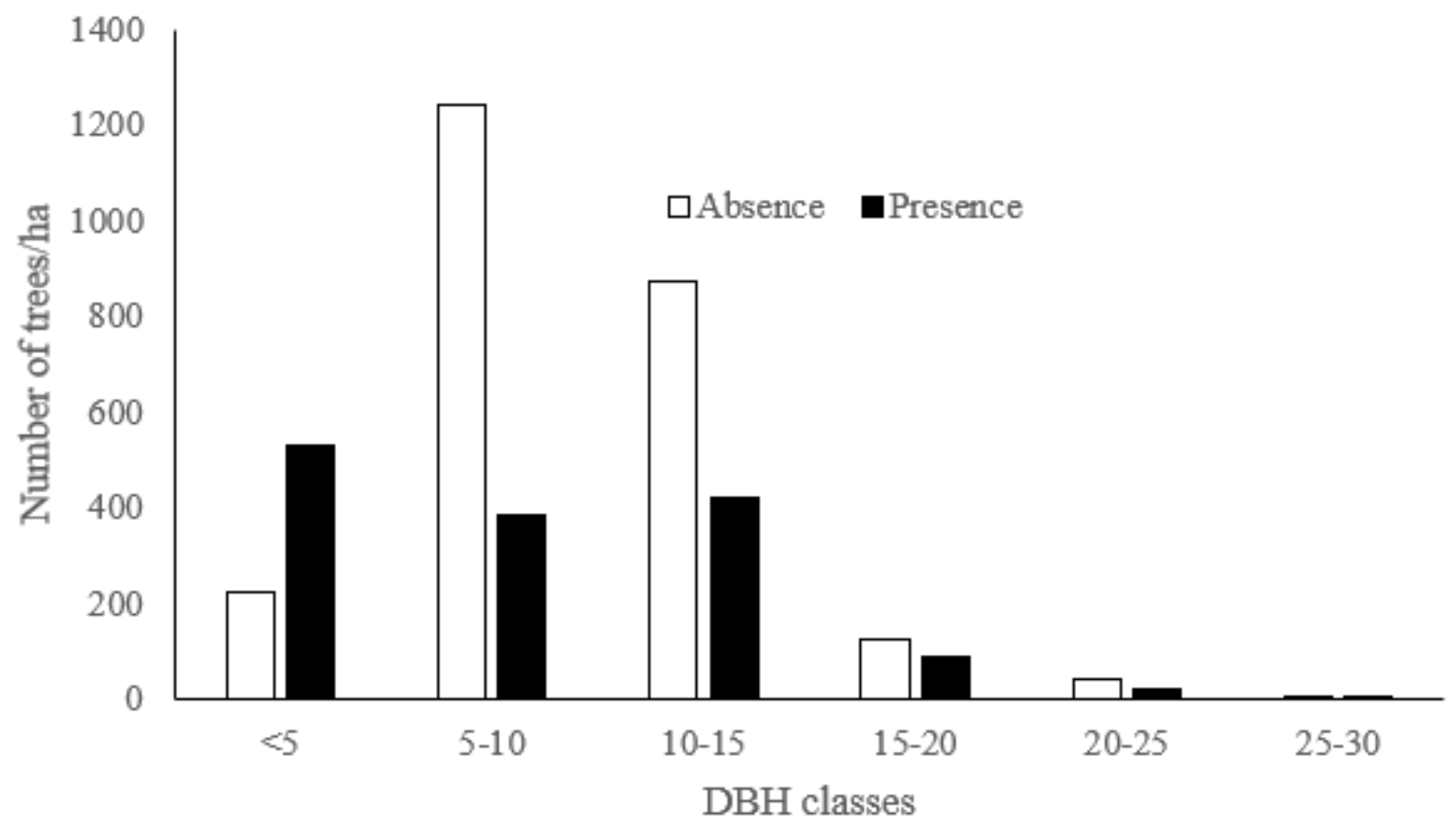

Figure 2

Frequency of overstorey trees in the different DBH classes in the Caucasian grouse absence and presence locations 


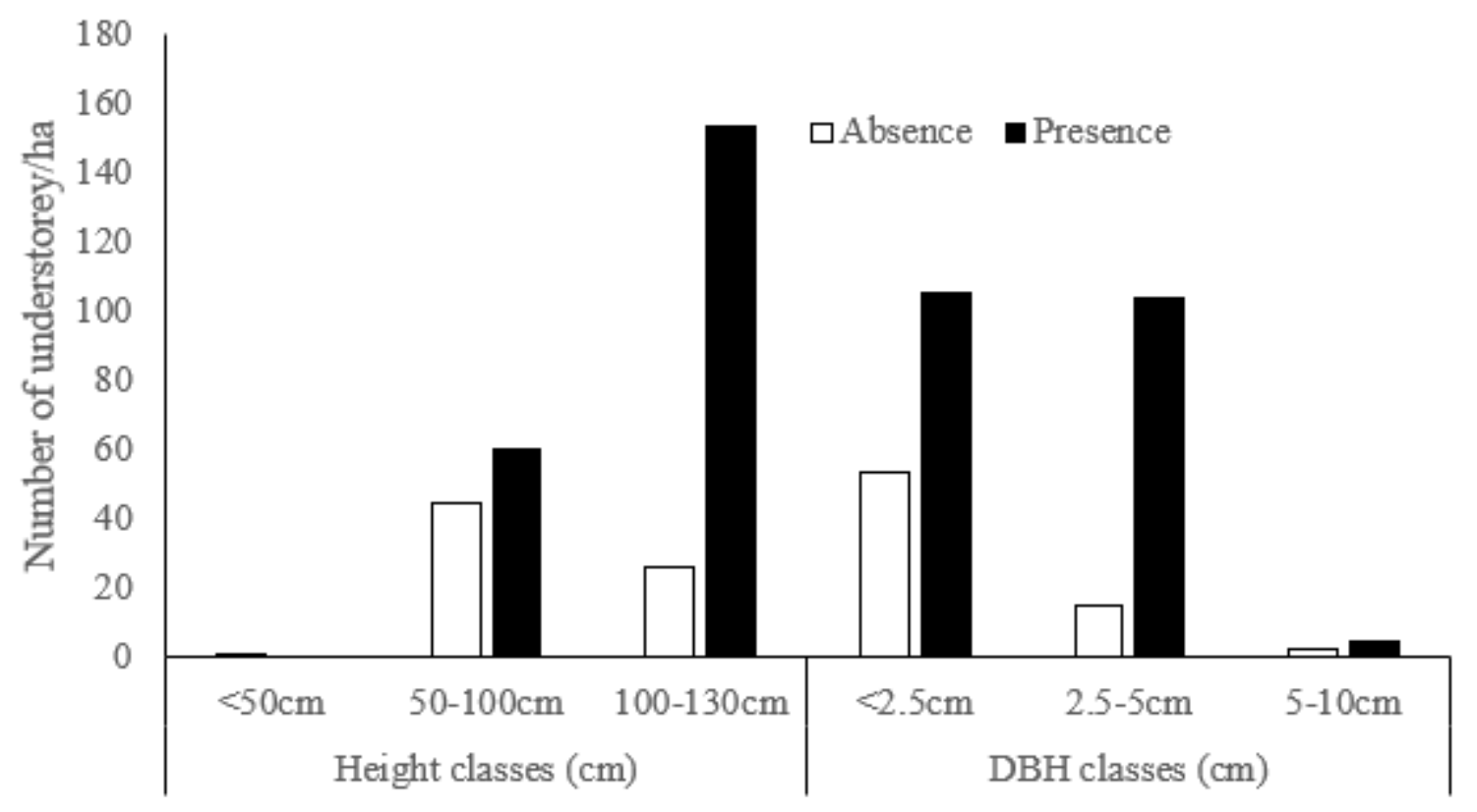

Figure 3

Frequency distribution of understorey trees in the different height and DBH classes in the absence and presence locations 

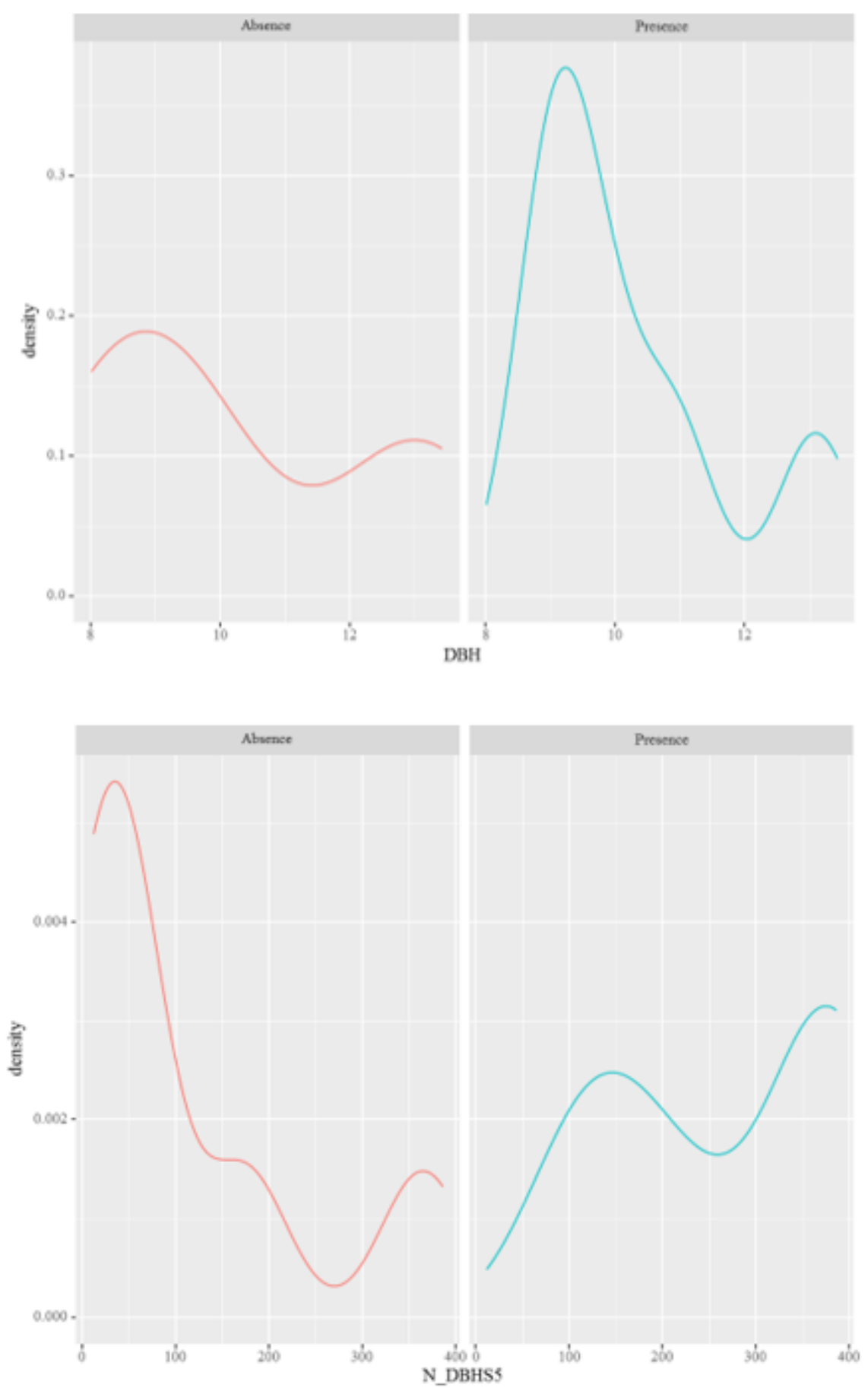

Figure 4

Density of all trees and trees with DBH smaller than $5 \mathrm{~cm}$ in the absence and presence locations 

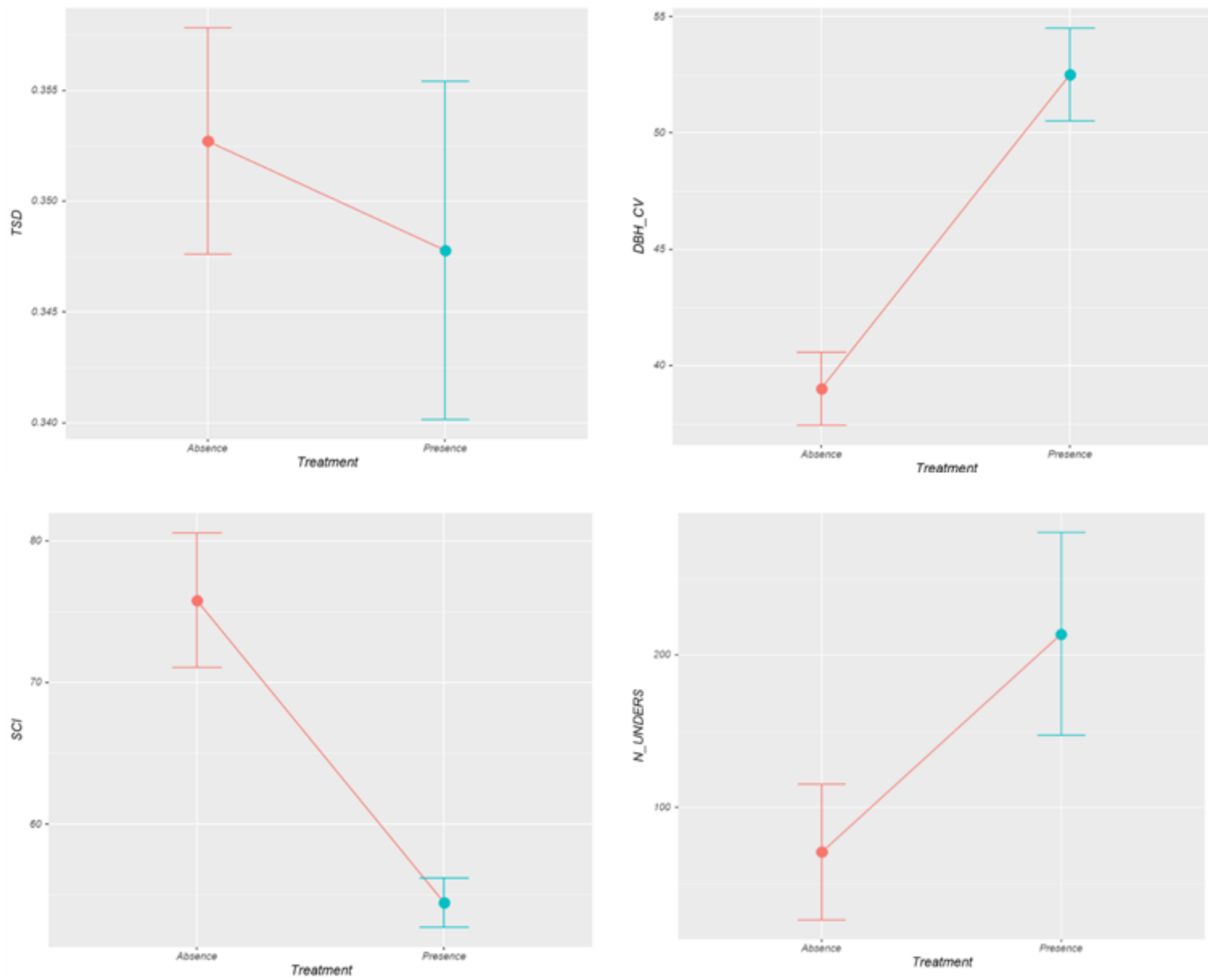

\section{Figure 5}

Differences in some attributes in two absence and presence locations of the Caucasian grouse 

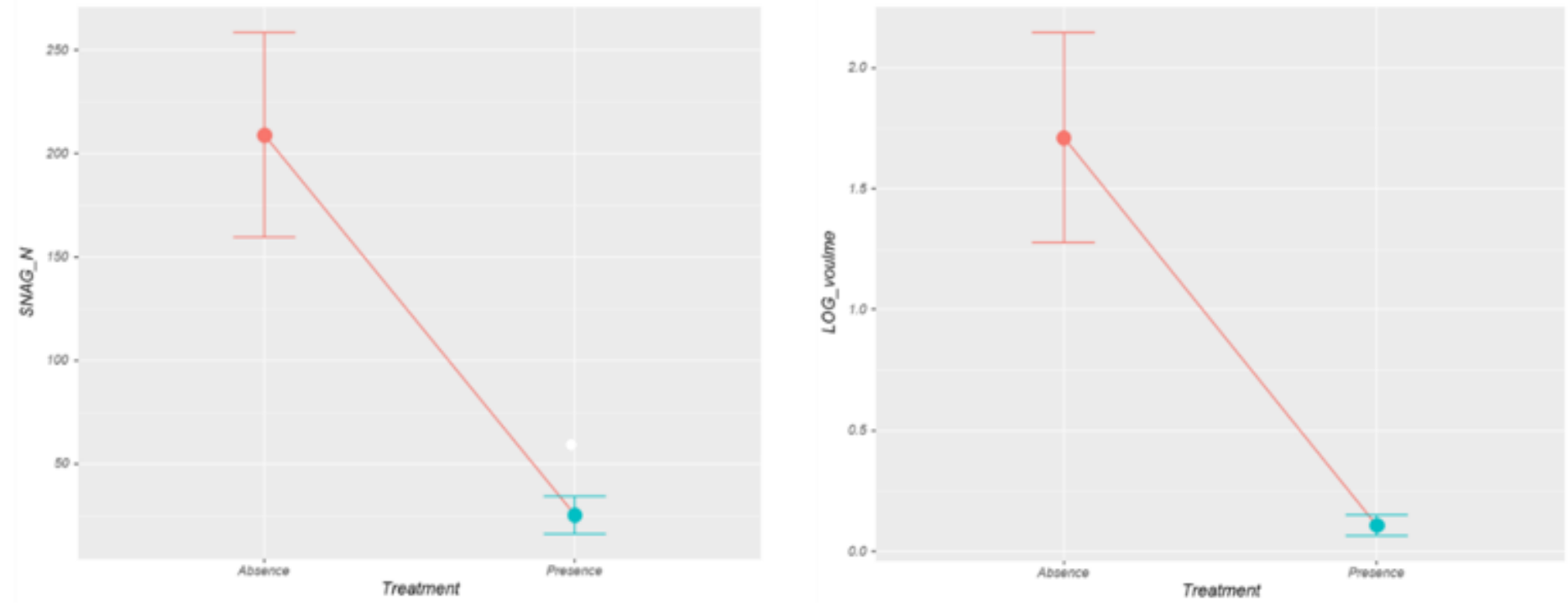

Figure 6

Number of dead trees and log volume in the Caucasian grouse absence and presence locations 